\title{
Suggestions and Recommendations of Face Mask Usage during COVID 19 Pandemic
}

\author{
Nafisa Abedin ${ }^{1}$, Kazi Nabila Bushrah ${ }^{2}$, Muhit Reza Md. Muktadir ${ }^{3}$, Raisa Abedin Disha ${ }^{4}$, \\ Saumitra Chakravarty ${ }^{5}$
}

${ }^{1}$ Resident, Department of Pathology, Bangabandhu Sheikh Mujib Medical University, Dhaka. Bangladesh; ${ }^{2}$ Trainee, Shaheed Suhrawardy Medical College, Dhaka, Bangladesh; ${ }^{3}$ Medical Officer, National Tuberculosis Program, Rangpur Dinajpur Rural Service (RDRS), Bangladesh; ${ }^{4}$ Masters in Information Systems Security, Bangladesh University of Professionals, Bangladesh; ${ }^{5}$ Assistant Professor, Department of Pathology, Bangabandhu Sheikh Mujib Medical University, Dhaka. Bangladesh

[Received: 17 October 2019; Accepted: 12 April 2020; Published: 1 June 2020]

\begin{abstract}
Rate of spread of SARS-CoV-2 and number of relevant deaths continue to elevate as the time elapses since its first outbreak. With no readily available curative treatment neither any effective vaccine till now to prevent the infection, practicing personal protection measures remain the only effective way to stay protected from its attack. Those who are directly exposed to the care of any confirmed or suspected COVID-19 patient, including the health care workers and caregivers, have been advised by the World Health Organization (WHO) and Centre for Disease Control and Prevention (CDC) to wear proper face masks or respirators following the guidelines. Transmission of corona virus occurs through respiratory droplets, close personal contact as well as touching stuff or surfaces polluted by the viral particles. However, several studies have already proven the effectiveness of using various face masks, according to the circumstances, in preventing the dissemination of COVID-19. [Bangladesh Journal of Infectious Diseases, June 2020;7(1):27-32]

Keywords: Face masks; prevention; Covid-19 pandemic

Correspondence: Dr. Nafisa Abedin, Resident, Department of Pathology, Bangabandhu Sheikh Mujib Medical University, Shagbag, Dhaka, Bangladesh; Email: nafia.abedin@gmail.com; Cell no.:+8801671534626

Conflict of interest: Authors declare that there is no conflict of interests.

Funding agency: The study was not funded by any authority.

Contribution to authors: Muhit Reza Md Muktadir, Raisa Abedin Disha involved in protocol preparation, data collection and literature search up to manuscript writing. Nafisa Abedin, Kazi Nabila Bushrah, Saumitra Chakravarty involved in literature search, preparation and revision of this manuscript.

How to cite this article: Abedin N, Bushrah KN, Muktadir MRM, Disha RA, Chakravarty S. Suggestions and Recommendations of Face Mask Usage during COVID 19 Pandemic. Bangladesh J Infect Dis 2020;7(1):27-32

Copyright: $\odot 2020$. Abedin et al. Published by Bangladesh Journal of Infectious Diseases. This article is published under the Creative Commons CC BY-NC License (https://creativecommons.org/licenses/by-nc/4.0/). This license permits use, distribution and reproduction in any medium, provided the original work is properly cited, and is not used for commercial purposes.
\end{abstract}

\section{Introduction}

The outbreak of coronavirus disease 2019 (COVID19) was initiated in Wuhan, China, in December 2019. With continuing spread of this infection to different parts of the world, World Health Organization (WHO) has made an announcement on the manifestation as a pandemic on March 11, $2020^{1}$. Although sharing similar properties of other respiratory viruses for example mode of 
transmission via respiratory droplet and contact $^{2,3}$, incubation period of 2 to 14 days with a median of about 6 days $^{4}$, SARS-CoV-2 has shown to have higher rates of mortality that is 6.5 percent globally, as of May 21, 2020 with some regional variations ${ }^{3}$.

Neither any effective vaccine nor any specific antiviral seem to be available till now, hence, preventive measures appear to be the armors of choice to fight against this deadly battle ${ }^{5}$. These include washing hands with soap water for at least 20 seconds or using alcohol based hand-rub at frequent intervals, refraining from touching eyes, nose and mouth with unclean hands, avoiding exposure to the sick people, following the respiratory etiquettes while sneezing and coughing, maintaining cleanliness of frequently used objects and surfaces, and seeking medical advice upon any suspicious exposure or symptoms ${ }^{6}$. As the health care workers directly confront any new outbreak, they should always follow and practice the infection prevention directives on a routine basis, and as a part of it, any exposure to a suspected COVID-19 patient should warrant an immediate placement of N95 respirator. However, in an effort to protect the caregivers or whoever is involved with direct patient care, application of medical masks has proven to be as significantly effective as N95 respirators ${ }^{3}$.

\section{Types of Mask}

Two categories of face masks are available at present ${ }^{7}$.

1. Medical mask (also known as surgical mask): These are made up of non-woven polypropylene material, flattened (some are cup-shaped) with or without being pleated and fastened to the head using straps. It is recommended by WHO that medical masks and respirators should be dispensed to the health care workers only ${ }^{7}$. Medical masks with wide variability in filtration capacity are found to allow penetration of tiny aerosol particles varying from $4 \%-90 \%$. Furthermore, after a sneeze or vigorous cough, all sided open surgical masks permit particle to escape around the mask's edges. However, for protecting Health Care Workers $(\mathrm{HCW})$ from respiratory infection for example, Influenza, surgical masks seem to be noninferior to $\mathrm{N}-95$ respirator in routine health care setup ${ }^{8}$.

2. N-95 respirators and equivalent: Korean Ministry of Health and Welfare recommended N-95 respirators and its equivalent like KN95,FFP2 etc for $\mathrm{HCW}$ to prevent inhalation of minute infectious particles(less than 5um) admixed with dust ${ }^{8}$. Additionally, in comparison to ordinary surgical mask, N-95 respirators and the equivalent ones are proven to afford better respiratory defense against aerosol particles as the respirators can filter out at least $95 \%$ pertinent aerosol particles. Importantly, $\mathrm{N}-95$ respirator masks as well as its equivalents are recommended in circumstances with excessive risk of aerosolization, such as, bronchoscopy and intubation. However, in developing countries, two issues are of concern in massive utilization of respirators specifically cost factors and user compliance ${ }^{9}$.

3. Non-medical mask: In contrast, these are made up of woven cotton fabric with a larger pore size than the medical masks. The implications of wearing these masks by the healthy group of people in the community require to be determined by extensive experimentation, as recommended by WHO. Meanwhile, a makeshift directive towards the use of non-medical masks may be issued by the decision makers. In congruence, the essential criteria of non-medical masks are stated below: ${ }^{7,10}$

a) Type of material being used: Cotton fabric, bandana cloth, T-shirt etc.

b) Number of layers of fabric/tissue: minimum of two layers.

c) Multiple layered fabrics to be used that do not pose any breathing restriction

d) Water resistant properties of the material

e) Having ties or ear loops to ensure comfortable fitting of the mask.

f) Reusable after being laundered and machine dried without any damage or alteration to the shape.

\section{Instructions on Wearing a Mask ${ }^{11}$}

- First of all, adequate cleaning hands either with soap water or alcohol based hand rub is essential before putting on a mask in order to manage a suspected or confirmed COVID-19 case.

- While using respirators, a proper fitting test should be performed to comply with the manufacturer's guidelines.

- In an effort to ensure irrevocable, expedite and durable fit, accurate adjustment of the metal nose clip and straps are necessary.

- When a satisfactory attachment may not seem achievable, a crosswise positioning of the straps may be of aid.

- In cases of surgical masks, as an alternative to the respirators, a proper fit and adjustment are advisable through using the metal nose clips. 


\section{Indications of using masks}

Endangered group of people such as elderly and those with co-morbid conditions, should put on face masks in any circumstances ${ }^{12}$. However, draping nose and mouth with different categories of face masks is highly advisable in the following circumstances:

\section{In the community}

- The health care workers must have adequate accessibility for use of medical masks.

- Additionally, all individuals including symptomatic ones suffering from high temperature, weakness, cough, sore throat, breathlessness etc. should also wear a medical mask to reduce transmission from the wearer?

\section{At Home}

- Any person exhibiting, mild symptoms or suspected as COVID-19 case should use a medical mask to the most feasible extent. Notably, the used masks should be discarded on a daily basis.

- Besides that, each person, including caregivers, exposed to a suspected COVID-19 case or with mild symptoms should also wear a medical mask with the same instructions of use ${ }^{7}$.

\section{Health Care Facility}

- All individuals symptomatic or not(except people with respiratory distress and persons who cannot put off masks by themselves, for example, unconscious patients and children less than two years old $)^{10}$ must wear a medical mask while waiting in the triage as well as while being transported from one place to another place inside or outside the health care facility.

- However, isolation in a room does not necessitate wearing a medical mask.

- Health care workers must ensure wearing a medical mask while visiting suspected or confirmed COVID-19 patients.

- Procedures like -manual ventilation before intubation, non-invasive ventilation, endotracheal intubation, tracheotomy, bronchoscopy and cardiopulmonary resuscitation, etc. generally produce aerosol. Therefore, cautions need to be achieved with respirators like N95, FFP2 or equivalent along with face shields that prevent inhalation of minute viral particles through aerosol ${ }^{7}$.

Table 1: Types of face mask recommended for using during COVID-19 pandemic ${ }^{13}$

\begin{tabular}{|c|c|c|c|}
\hline Type of Facility & Type of User & Activity & Type of Mask Recommended \\
\hline \multicolumn{4}{|c|}{ Health Care Facilities } \\
\hline \multicolumn{4}{|c|}{ In-Patient Facility } \\
\hline \multirow[t]{4}{*}{ Patient room } & \multirow[t]{2}{*}{ Health care workers } & $\begin{array}{l}\text { Close contact with COVID-19 } \\
\text { patients while providing direct care }\end{array}$ & Medical mask \\
\hline & & $\begin{array}{l}\text { Performing aerosol-generating } \\
\text { procedure on COVID-19 patients }\end{array}$ & $\begin{array}{l}\text { Respirator N95 or FFP2 or } \\
\text { equivalent along with face shield }\end{array}$ \\
\hline & Cleaners & $\begin{array}{l}\text { Cleaning the rooms of COVID-19 } \\
\text { patients }\end{array}$ & Medical mask \\
\hline & Visitors & $\begin{array}{l}\text { Entering the room of a COVID-19 } \\
\text { patient }\end{array}$ & Medical mask \\
\hline $\begin{array}{l}\text { Rest of the places } \\
\text { of patient transit } \\
\text { (wards, corridors } \\
\text { etc.) }\end{array}$ & All staff & $\begin{array}{l}\text { No contact with COVID-19 } \\
\text { patients }\end{array}$ & Non-medical mask needed. \\
\hline \multirow[t]{3}{*}{ Triage } & Health care workers & $\begin{array}{l}\text { Primary screening not involving } \\
\text { direct contact }\end{array}$ & Non-medical mask needed \\
\hline & $\begin{array}{ll}\text { Patients } & \text { with } \\
\text { respiratory } & \\
\text { symptoms } & \end{array}$ & Any & $\begin{array}{l}\text { If tolerated by patient, medical } \\
\text { mask should be offered. }\end{array}$ \\
\hline & $\begin{array}{ll}\text { Patients } & \text { without } \\
\text { respiratory } & \\
\text { symptoms } & \end{array}$ & Any & Non-medical mask needed. \\
\hline Laboratory & Lab Technician & Manipulation & Medical mask \\
\hline
\end{tabular}




\begin{tabular}{|c|c|c|c|}
\hline & & samples & \\
\hline $\begin{array}{l}\text { Administrative } \\
\text { areas }\end{array}$ & $\begin{array}{l}\text { All staff, including } \\
\text { health care workers }\end{array}$ & $\begin{array}{l}\text { Administrative activities not } \\
\text { involving any exposure to COVID- } \\
19 \text { patients }\end{array}$ & Non-medical mask needed. \\
\hline \multicolumn{4}{|c|}{ Out-Patient Facilities } \\
\hline \multirow[t]{4}{*}{$\begin{array}{l}\text { Consultation } \\
\text { room }\end{array}$} & Health care workers & $\begin{array}{l}\text { Physical examination of patient } \\
\text { with respiratory complaints }\end{array}$ & Medical mask \\
\hline & $\begin{array}{l}\text { Patients with } \\
\text { respiratory symptoms }\end{array}$ & Any & If tolerated, offer medical mask \\
\hline & $\begin{array}{l}\text { Patients without } \\
\text { respiratory symptoms }\end{array}$ & Any & Non-medical mask needed. \\
\hline & Cleaners & $\begin{array}{l}\text { Cleaning the room following and } \\
\text { in between consultations with } \\
\text { patients having respiratory } \\
\text { symptoms }\end{array}$ & Medical mask \\
\hline \multirow[t]{2}{*}{ Waiting area } & $\begin{array}{l}\text { Patients with } \\
\text { respiratory symptoms }\end{array}$ & Any & If tolerated, offer medical mask \\
\hline & $\begin{array}{l}\text { Patients without } \\
\text { respiratory symptoms }\end{array}$ & Any & Non-medical mask needed. \\
\hline $\begin{array}{l}\text { Administrative } \\
\text { areas }\end{array}$ & $\begin{array}{l}\text { All staff, including } \\
\text { health care workers }\end{array}$ & Administrative tasks & Non-medical mask needed. \\
\hline \multirow[t]{3}{*}{ Triage } & Health care workers & $\begin{array}{l}\text { Primary screening not involving } \\
\text { direct contact }\end{array}$ & Non-medical mask needed. \\
\hline & $\begin{array}{l}\text { Patients with } \\
\text { respiratory symptoms }\end{array}$ & Any & $\begin{array}{l}\text { If tolerated by patient, medical } \\
\text { mask should be offered. }\end{array}$ \\
\hline & $\begin{array}{l}\text { Patients without } \\
\text { respiratory symptoms }\end{array}$ & Any & Non-medical mask needed. \\
\hline \multicolumn{4}{|l|}{ Community } \\
\hline \multirow[t]{4}{*}{ Home } & $\begin{array}{l}\text { Patients with } \\
\text { respiratory symptoms }\end{array}$ & Any & $\begin{array}{l}\text { If tolerated by patient, medical } \\
\text { mask should be offered, except } \\
\text { while sleeping. }\end{array}$ \\
\hline & Caregiver & $\begin{array}{l}\text { Accessing the patient's room, but } \\
\text { directly not involved in patient's } \\
\text { care or assistance }\end{array}$ & Medical mask \\
\hline & Caregiver & $\begin{array}{l}\text { Involved in direct patient care, or } \\
\text { disposal of COVID-19 patient's } \\
\text { excreta and waste }\end{array}$ & Medical mask \\
\hline & Health care workers & $\begin{array}{l}\text { Direct contact with COVID-19 } \\
\text { patient at home while providing } \\
\text { care or assistance }\end{array}$ & Medical mask \\
\hline $\begin{array}{lr}\text { Public } & \text { places } \\
\text { (schools, } & \\
\text { shopping } & \text { malls, } \\
\text { railway } & \text { stations } \\
\text { etc.) } & \\
\end{array}$ & $\begin{array}{l}\text { Individuals without } \\
\text { respiratory symptoms }\end{array}$ & Any & Non medical mask needed. \\
\hline \multicolumn{4}{|l|}{ Points of entry } \\
\hline $\begin{array}{l}\text { Administrative } \\
\text { Areas }\end{array}$ & All staff & Any & Non medical mask needed. \\
\hline \multirow[t]{3}{*}{ Screening areas } & Staff & $\begin{array}{l}\text { Primary screening (Temperature } \\
\text { measurement) not requiring direct } \\
\text { contact }\end{array}$ & Non medical mask needed. \\
\hline & Staff & $\begin{array}{l}\text { Secondary screening for example } \\
\text { interrogating passengers for } \\
\text { symptoms suggestive of COVID- } \\
19 \text { disease including travel } \\
\text { history. }\end{array}$ & Medical mask \\
\hline & Cleaners & $\begin{array}{l}\text { Cleaning the area where febrile } \\
\text { patients were screened }\end{array}$ & Medical mask \\
\hline $\begin{array}{l}\text { Ambulance or } \\
\text { transfer medium }\end{array}$ & Staff & $\begin{array}{l}\text { Accessing the area, but not } \\
\text { involved in direct assistance }\end{array}$ & Medical mask \\
\hline
\end{tabular}




\begin{tabular}{|c|c|c|c|}
\hline & $\begin{array}{l}\text { Staff, health care } \\
\text { workers }\end{array}$ & $\begin{array}{lll}\text { Assisting } & \text { in } & \text { passenger } \\
\text { transportation } & \text { to a health care } \\
\text { facility } & & \end{array}$ & Medical mask \\
\hline & Cleaners & Decontamination of isolation area & Medical mask \\
\hline & Health care workers & $\begin{array}{l}\text { Transportation of suspected } \\
\text { COVID-19 patients to the referral } \\
\text { health care facility }\end{array}$ & Medical mask \\
\hline & \multirow[t]{3}{*}{ Driver } & $\begin{array}{l}\text { Driving only the suspected } \\
\text { COVID-19 disease patient with a } \\
\text { separate driver's compartment }\end{array}$ & No mask needed. \\
\hline & & $\begin{array}{l}\text { Actively loading or unloading } \\
\text { suspected COVID-19 patient }\end{array}$ & Medical mask \\
\hline & & $\begin{array}{l}\text { Driving the suspected COVID-19 } \\
\text { patient with no separate driver's } \\
\text { compartment }\end{array}$ & Medical mask \\
\hline & $\begin{array}{ll}\text { Suspected COVID- } \\
19 \text { patient }\end{array}$ & $\begin{array}{l}\text { Being transported to the referral } \\
\text { health care facility }\end{array}$ & If tolerated, offer medical mask \\
\hline & Cleaners & $\begin{array}{l}\text { Decontamination following and in } \\
\text { between transportation of } \\
\text { suspected COVID-19 patients to } \\
\text { the referral health care facility }\end{array}$ & Medical mask \\
\hline \multicolumn{4}{|c|}{ Special importance to rapid-response teams assisting with public health investigations } \\
\hline \multicolumn{4}{|c|}{ Community } \\
\hline \multirow[t]{2}{*}{ Anywhere } & \multirow[t]{2}{*}{$\begin{array}{l}\text { Rapid-response team } \\
\text { investigators }\end{array}$} & $\begin{array}{l}\text { Interrogating suspected or } \\
\text { confirmed COVID-19 patients or } \\
\text { their contacts }\end{array}$ & $\begin{array}{l}\text { If done from distance (e.g. over } \\
\text { telephone or virtual meeting), no } \\
\text { mask is needed }\end{array}$ \\
\hline & & $\begin{array}{l}\text { Face to face interrogation without } \\
\text { any direct contact with any } \\
\text { suspected or confirmed COVID- } \\
19 \text { patient }\end{array}$ & Medical mask \\
\hline
\end{tabular}

\section{Table 2: Dos and DON'Ts of mask usage ${ }^{7}$}

\begin{tabular}{|c|c|}
\hline Dos & DON'Ts \\
\hline $\begin{array}{l}\text { - Tight fit placement of the mask draping the mouth } \\
\text { and nose as well as to ensure the least free space } \\
\text { between the face and the mask. } \\
\text { - Abstaining from touching the mask while wearing } \\
\text { it. } \\
\text { - Following every removal or after every, if any, } \\
\text { unintentional touch, hands must be cleaned by an } \\
\text { alcohol-based hand rub or alkaline soap and water. } \\
\text { - Damp masks require quickest disposal, and need to } \\
\text { be replaced with a new clean and dry one. }\end{array}$ & $\begin{array}{l}\text { - DO NOT touch the front of the mask but untie from } \\
\text { back. } \\
\text { - DO NOT reuse the one time use masks. }\end{array}$ \\
\hline
\end{tabular}

\section{Durability of Mask Usage}

- The standard respirators- N95, FFP2 or other equivalent respirators can be used for prolonged hours during treating patients with identical diagnosis. Nevertheless, a single respirator may cause discomfort if worn uninterruptedly for more than 4 hours and, hence, should be put off accordingly ${ }^{13}$.
- A study by Ahmed et $\mathrm{al}^{14}$ stated that usage of face masks by the health care workers for at least 6 hours can significantly reduce infection rate.

\section{Recycling and Decontamination}

Being made of degradable materials, standard methods of disinfection for instance boiling, heating, or using chemical and radiation are apparently practically unsuitable for recycling of mask! Therefore, no single standard mean seems to 
be available for effective disinfection of disposable masks and respirators. However, few processes, for example, Ultraviolet germicidal irradiation (UVGI), microwave generated steam (MGS), moist heat $(\mathrm{MH})$, ethylene oxide and vaporized hydrogen peroxide etc. have been recommended as alternatives to decontaminate respirators ${ }^{15}$.

In the face of scarcity, All India Institute of Medical Science(AIMS) and Bangabandhu Sheikh Mujib Medical University (BSMMU) recommended extended use of N95 masks for HCWs by providing them with five N95 masks with five small paper made bags for every 20 days. HCWs are advised to keep each of their supplied masks in paper bag after having completed their duty to dry it out for subsequent four days. The same maneuver is applicable for another three N95 masks and the fifth one is advised to keep preserved. After four days the respirator can be used again. AIMS also recommended to use each of the respirator for maximum five times as per advice of $\mathrm{CDC}$, Atlanta ${ }^{16}$.

\section{Ideal Method of Mask Disposal}

Each used mask should be disposed in a leaded container. In addition, prior to wearing and following removal of a mask, proper hand hygiene must be ensured ${ }^{13}$.

\section{Conclusion}

Researchers and scientists are working hard day and night to find out the effective vaccine and specific drug to minimize the spread and mortality caused by corona virus. Meanwhile, using different categories of face masks in specific circumstances, keeping social distance (at least 2 meters), maintaining personal hygiene etiquettes and covering face while sneezing and coughing can provide a shield from this alarming infestation. Face mask alone should not be considered as an excuse to disregard other health measures as mentioned here. Additionally, being the frontline fighters, the health care workers must properly abide by the recommendations approved by the health care authorities with utmost priority for their protection.

Acknowledgement: We would like to thank Dr. Ferdousy Begum, Associate Professor, Chairman of Department of
Pathology, Bangabandhu Sheikh Mujib Medical University (BSMMU), Dr. Abu Saleh, Professor and Chairman, Department of Microbiology, Dr. Chandan Kumar Roy, Assistant Professor, Department of Microbiology, Dr. Latifa Nishat, Assistant Professor, Department of Anatomy, Dr. Abu Nayem Md. Iftekharul Islam, resident, pathology, Bangabandhu Sheikh Mujib Medical University (BSMMU) for their valuable suggestions and affectionate guidance.

\section{References}

1. World Health Organization W. WHO Director-General's opening remarks at the media briefing on COVID-19 - 11 March 2020. WHO Dir Gen speeches. 2020;(March):4.

2. Bowdle A, Munoz-Price LS. Preventing Infection of Patients and Healthcare Workers Should Be the New Normal in the Era of Novel Coronavirus Epidemics. Anesthesiology. 2020; (Xxx):1-4.

3. Adams JG, Walls RMW. Supporting the Health Care Workforce During the COVID-19 Global Epidemic. JAMA - J Am Med Assoc. 2020;323(15):1439-40.

4. Jernigan DB. Update: Public health response to the coronavirus disease 2019 outbreak - United States, February 24, 2020. Morb Mortal Wkly Rep. 2020;69(8):216-9.

5. Rio C, Malani NP. 2019 Novel Coronavirus -Important Information for Clinicians. N Engl J Med. 2020;382(10):92936.

6. Graham CW, Dela CCS, Cao B, Pasnick S, Jamil S. Novel Wuhan (2019-NCoV) coronavirus. Am J Respir Crit Care Med. 2020;201(4):P7-8.

7. World Health Organization. Advice on the use of masks in the context of COVID-19. 2020;(March):1-2.

8. Kim H, Baek JE, Seo HK, Lee JE, Myong JP, Lee SJ, et al. Assessing real-time performances of $\mathrm{n} 95$ respirators for health care workers by simulated workplace protection factors. Ind Health. 2015;53(6):553-61.

9. Gupta S. Surgical masks vs. N95 respirator masks for protecting health care professionals. Indian $\mathrm{J}$ Pediatr. 2011;78(2):242-3.

10. Prevention(CDC) $\mathrm{C}$ for disease control and. Use of Cloth Face Coverings to Help Slow the Spread of COVID-19. cdc.gov/coronavirus. 2020;4-6.

11. Report. EC for DP and CT. Guidance for Wearing and Removing personal protective equipment in healthcare settings for the care of patients with suspected or confirmed COVID19. 2020;1-13.

12. Feng S, Shen C, Xia N, Song W, Fan M, Cowling BJ. Rational use of face masks in the COVID-19 pandemic. Lancet Respir Med [Internet]. 2020;2(20):2019-20.

13. World Health Organization (WHO). Rational use of personal protective equipment for coronavirus disease 2019 ( COVID-19 ). WHO. 2020;2019(February):1-7.

14. Chughtai AA, Stelzer-Braid S, Rawlinson W, Pontivivo G, Wang Q, Pan Y, et al. Contamination by respiratory viruses on outer surface of medical masks used by hospital healthcare workers. BMC Infect Dis 2019;19(1):1-8.

15. Chughtai AA, MacIntyre CR, Zheng Y, Wang Q, Toor ZI, Dung TC, et al. Examining the policies and guidelines around the use of masks and respirators by healthcare workers in China, Pakistan and Vietnam. J Infect Prev. 2015;16(2):68-74. 16. Science AII of M. Mask Use. Ansari Nagar, New Delhi; 2020. 